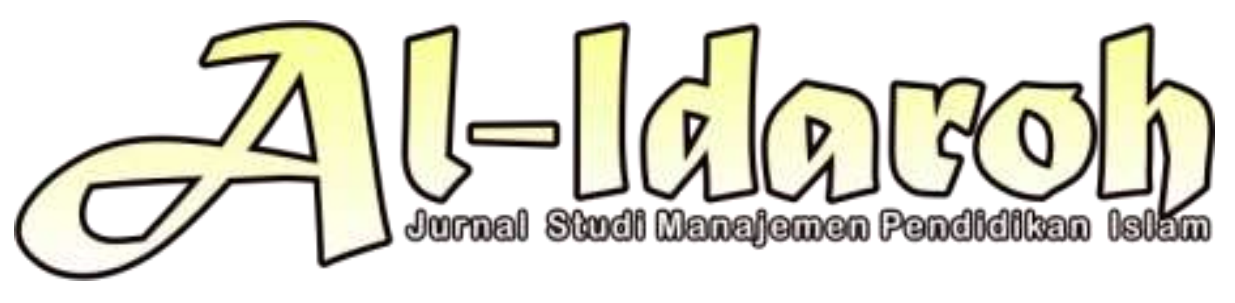

\title{
MENINGKATKAN MUTU PENDIDIKAN ISLAM DI MADRASAH DINIYAH BABUS SALAM BLINGOH DONOROJO JEPARA
}

\author{
Ashif Az Zafi \\ Institut Agama Islam Negeri Kudus \\ Email: ashifazzafi@iainkudus.ac.id \\ A'yun Qulubana \\ Institut Agama Islam Negeri Kudus \\ Email: ayunayun3456@gmail.com \\ Eva Luthfi Fakhru Ahsani \\ Institut Agama Islam Negeri Kudus \\ Email: evaluthfi@iainkudus.ac.id \\ Elya Umi Hanik \\ Institut Agama Islam Negeri Kudus \\ Email: elyaumi@iainkudus.ac.id
}

\begin{abstract}
Madrasah Diniyah is a non-formal Islamic educational institution. To become a pend institution. Islam requires high seriousness and motivation, high seriousness and motivation so that the goals and expectations of Madrasah Diniyah are achieved. Madrasas must continue to be an inspiration and motivation in minimizing the current moral crisis by instilling good morals in students through Islamic religious learning. This research is classified as a descriptive qualitative research conducted at Madrasah Diniyah Babus Salam Blingoh Donorojo Jepara. The purpose of this study was to find out how to improve the quality of education in Madrasah Diniyah Babus Salam. While the method of data collection using the method of observation and interviews. From the results of the study, it can be said that in improving the quality of Madrasab Diniyah education there are three elements, namely input, process, and output, but in its realization there are many obstacles in improving the quality of education in the field, namely social and economic problems.
\end{abstract}

Keywords: Quality, Islamic Education, Madrasah Diniyah 


\section{Meningkatkan Mutu Pendidikan Islam di Madrasah Diniyah Babus Salam \\ Blingoh Donorojo Jepara}

\section{Pendahuluan}

Madrasah Diniyah adalah salah satu lembaga pendidikan Islam yang memiliki tujuan untuk menyiapkan peserta didik dalam memahami dan mengamalkan nilainilai ajaran agama Islam serta memiliki wawasan luas dalam rangka untuk mencerdaskan kehidupan bangsa agar menjadi orang yang bertakwa dan beriman serta berakhlak mulia. Kedudukan Madrasah Diniyah dalam lembaga pendidikan merupakan pelengkap dari sekolah pendidikan formal. Madrasah Diniyah merupakan bentuk madrasah pertama yang terdapat di Indonesia. Madrasah Diniyah merupakan salah satu pendidikan Islam yang masuk dalam kategori pendidikan non formal. Namun pada era globalisasi ini Madrasah Diniyah menjadi lembaga pendidikan yang dipandang sebelah mata. Hal tersebut dikarenakan Madrasah Diniyah di Indonesia baru mendapat pengakuan dan perhatian khusus dari pemerintah pada akhir-akhir ini yang terdapat pada UU Nomor 20 Tahun 2003 tentang sistem pendidikan nasional, yang dikuatkan pula dengan PP. Nomor 55 Tahun 2003 yakni dengan syarat Madrasah Diniyah tersebut memuat pembelajaran (kurikulum) yang di anjurkan oleh pemerintah. Madrasah Diniyah sendiri memiliki ciri khas selain materi yang diajarkan, terdapat pula prinsip pendidik. Tenaga pendidik di Madrasah Diniyah menggunakan prinsip keikhlasan.

Dalam hidup semua manusia pasti melangsungkan hidupnya dengan dasar yang dijadikan pedoman dari segala aktivitas yang akan di lakukannya. Begitupun juga mdarasah diniyah, Madrasah Diniyah memiliki dasar-dasar antara lain: Pertama, dasar religius yaitu dasar yang bersumber dari ajaran Islam yang tercantum dalam al-Qur'an dan Hadits. Kedua, dasar Yuridis atau hukum yaitu dasar dari pancasila, UndangUndang dasar 1945 dan dasar operasional yakni UU RI Nomor 20 Tahun 2003 tentang sistem pendidikan nasional.

Madrasah Diniyah Babus Salam yang terletak di desa Blingoh 02/01 Donorojo Jepara merupakan sebuah lembaga non formal yang memiliki yayasan tersendiri yaitu Babus Salam, Madrasah Diniyah Babus Salam berusaha sebaik mungkin dalam mempersiapkan peserta didik yang unggul serta berwawasan luas dan memiliki kepribadian yang baik atau berakhlakul karimah. Selain mempersiapkan peserta didik yang baik, Guru merupakan peranan penting dalam meningkatkan mutu pendidikan, keberhasilan pembelajaran yang bermutu juga tidak terlepas dari strategi 
pembelajaran, metode pembelajaran, model pembelajaran, juga sarana prasarana yang terpenuhi dalam proses pembelajaran.

Meningkatkan mutu pendidikan di Madrasah Diniyah sangat penting dilakukan karena sekarang ini masyarakat menanggap bahwa Madrasah Diniyah bukan hal penting bagi pendidikan anak-anaknya, karena sudah terdapat lembaga formal seperti sekolah. Anggapan ini yang menjadikan Madrasah Diniyah jauh dari kata maju. Padahal lahirnya lembaga pendidikan Islam Madrasah Diniyah menjadikan salah satu solusi yang tepat dalam meminimalisir krisis moral yang terjadi pada saat ini. Hal ini dikarenakan Madrasah Diniyah merupakan lembaga yang memberikan pelajaran agama kepada peserta didik, dengan hal itu Madrasah Diniyah merupakan pelengkap atau tambahan bagi pembelajaran yang terdapat di sekolah.

Dalam meningkatkan mutu pendidikan Islam, seorang pendidik mempunyai peran yang sangat besar, selain itu keberhasilan pembelajaran yang bermutu juga tidak terlepas dari strategi pembelajaran dalam mewujudkan suatu tujuan pendidikan. Agar kegiatan pembelajaran tersebut bermutu, maka seorang pendidik harus bisa membuat kelas menjadi menyenangkan, dan juga seorang guru harus menerapkan hal-hal yang berkaitan dengan perubahan tingkah laku serta menumbuhkan motivasi, bakat, minat peserta didik. Selain itu dapat memberikan pelayanan yang bermutu yang sifatnya masif dan terbuka untuk dengan mudah menjangkau minat masyrakat yang lebih luas ${ }^{1}$.

Di era sekarang ini, banyak masyarakat yang mengganggap Madrasah Diniyah tidak penting dalam pendidikan Islam, hal ini terjadi dikarenakan kurangnya mutu pendidikan yang terdapat di dalam Madrasah Diniyah. Terdapat banyak kendala dalam meningkatkan mutu pendidikan Islam di Madrasah Diniyah. Salah satunya yakni dalam penerapan kurikulum, karena dapat diketahui bahwa kurikulum Madrasah Diniyah belum ada yang tertulis, dan begitu juga SDM yang kurang mendapatkan perhatian dari pemerintah ${ }^{2}$. Sedangkan menurut Nizah ${ }^{3}$ juga

\footnotetext{
${ }^{1}$ Aisah Isnaeni and Eva Luthfi Fakhru Ahsani, "Strategi Pembelajaran Daring Dengan Model Resitasi Berbasis Teknologi Bagi Siswa MI/SD," As-Sibyan 3, no. 2 (2021): 12-20, https://doi.org/10.52484/as_sibyan.v3i2.196.

${ }^{2}$ Muhammad Ripin Ikwandi, "Peran Madrasah Diniyah Dalam Peningkatan Mutu," EDUSLANA: Jurnal Manajemen Dan Pendidikan Islam 4, no. 1 (2017): 32-45.

${ }^{3}$ Nuriyatun Nizah, "Dinamika Madrasah Diniyah : Suatu Tinjauan Historis," Edukasia 11, no. 1 (2016): 181-202.
} 


\section{Meningkatkan Mutu Pendidikan Islam di Madrasah Diniyah Babus Salam \\ Blingoh Donorojo Jepara}

mengatakan bahwa untuk mempertahankan eksistensi Madrasah Diniyah agar tetap diminati oleh masyarakat sekitar diperlukan adanya strategi, yaitu penyelenggaraan pembelakalan untuk guru mengenai materi, metode, dan strategi yang sesuai bagi kompetensi Madrasah Diniyah, penyelenggaraan pembinaan untuk Madrasah Diniyah (meliputi manajemen dan pembelajaran). Dari penelitian terhadulu ${ }^{4}$ dalam jurnal yang berjudul "Learning Management In Improving The Quality Of Graduates Madrasah Diniyah Takmiliyah Awaliyah (MDTA) In Sukabumi District" dikatakan bahwa dalam meningkatkan kualitas Madrasah Diniyah terhalang oleh anggaran bantuan serta pengawasan dan pembinaan yang belum optimal, namun dalam manajemen pembelajaran sudah cukup untuk memenuhi kompetensi lulusan.

Berdasarkan uraian diatas, dapat disimpulkan bahwa Madrasah Diniyah masih sangat jauh dalam segi mutu pendidikan, sehingga peneliti ingin mengkaji tentang mutu pendidikan Madrasah Diniyah dan juga melihat bagaimana mutu pendidikan yang terdapat di lapangan dengan cara menggali informasi tentang mutu pendidikan Islam di Madrasah Diniyah, dan juga hambatan-hambatan yang terdapat di lapangan sehingga membuat Madrasah Diniyah menjadi madrasah yang kurang dalam segi kualitasnya, dan jarang diminati oleh masyarakat, sehingga dapat ditarik kesimpulan untuk menentukan bagaimana cara meningkatkan mutu pendidikan Madrasah Diniyah Babus Salam Blingoh Donorojo Jepara agar masyarakat mulai tertarik memasukkan anaknya untuk belajar di Madrasah Diniyah.

\section{Metode Penelitian}

Penelitian ini merupakan penelitian kasus (case study) di Madrasah Diniyah Babus Salam di Blingoh Donorojo Jepara. Jenis penelitian yang digunakan adalah penelitian deskriptif kualitatif yang bertujuan untuk menganalisis dan menjelaskan mutu pendidikan di Madrasah Diniyah Babus Salam di Blingoh Donorojo Jepara. Teknik pengumpulan data yang digunakan dalam penelitian ini adalah wawancara, observasi dan analisis dokumen.

\section{Hasil dan Diskusi Penelitian}

\footnotetext{
${ }^{4}$ Usman Armaludin, "Learning Management in Improving the Quality of Graduates Madrasah Diniyah Takmiliyah Awaliyah (MDTA) in Sukabumi District," International Journal of Nusantara Islam 9, no. 1 (2021): 70-79, https://doi.org/10.15575/ijni.v9i1.11918.
} 


\section{Mutu Pendidikan Madrasah Diniyah}

Mutu pendidikan merupakan kemampuan sebuah lembaga dalam meningkatkan kualitas lulusan (output) sesuai dengan tujuan dan harapan pendidikan melalui pembelajaran yang efektif. Terdapat tiga output dalam mutu pendidikan. Pertama, Ranah kognitif yaitu ranah yang yang menyangkut segala aktifitas otak. Kedua, Ranah afektif yakni ranah yang terkait dengan emosi. Ketiga, Ranah Psikomotorik yakni ranah yang meliputi gerakan dan kondisi jasmani.

Madrasah berasal dari bahasa Arab yang artinya dzaraf makan dari akar darasa. Secara harfiah madrasah memiliki arti tempat belajar. Madrasah jika diartikan dalam bahasa Indonesia memiliki arti sekolah, namun kata sekolah bukan berasal dari bahasa Indonesia melainkan bahasa asing yaitu school atau scola. Madrasah lebih dispesifikkan yaitu sekolah agama atau biasa disebut Madrasah Diniyah yakni tempat dimana peserta didik mendapatkan pembelajaran tentang agama Islam. ${ }^{5}$ Sedangkan menurut Haidar Putra Daulay mengatakan bahwa Madrasah Diniyah yaitu madrasah yang mengajarkan ilmu-ilmu agama saja, dan tujuan dari dirikannya Madrasah Diniyah merupakan penyempurnaan dalam melengkapi pendidikan agama yang dilaksanakan di sekolah. Dalam proses pembelajaran Madrasah Diniyah memiliki tiga unsur yaitu pendidik, peserta didik, dan kurikulum. Kesemuanya saling keterkaitan atau berhubungan satu sama lain, sehingga unsur-unsur tersebut harus berjalan secara seimbang dan terstruktur. Pendidik merupakan seorang yang menstranferkan ilmunya melalui proses pembelajaran, dalam mentransferkan ilmu seorang pendidik harus memiliki keterampilan mengajar, mengelola tahapan belajar, menggunakan metode yang kreatif dan inovatif. Pendidik merupakan guru rohani bagi peserta didik dalam hal keagamaan, oleh karena itu seorang pendidik harus bisa membimbing dan membina peserta didik agar dapat memiliki kepribadian yang baik dan berakhlakul karimah. Sedangkan peserta didik merupakan anggota masyarakat yang mengembangkan potensi dirinya melalui proses pembelajaran yang sudah disediakan pada lembaga-lembaga pendidikan. Yang dimaksud peserta didik disini adalah peserta didik yang berhak mendapatkan pendidikan fomal dan non-formal.

${ }^{5}$ A.W Munawwir, Kamus Bahara Arab-Indonesia (Surabaya: Pustaka Progesif, 2002). 


\section{Meningkatkan Mutu Pendidikan Islam di Madrasah Diniyah Babus Salam \\ Blingoh Donorojo Jepara}

Selain itu peserta didik juga merupakan seseorang yang mendapatkan pelayanan pendidikan sesuai dengan bakat minat yang dimilikinya sesuai dengan kemampuan pada masing-masing peserta didik. Dua pokok yang harus dipersiapkan oleh peserta didik ketika memasuki pembelajaran adalah menyiapkan batiniyah dirinya (dengan hati dan niat belajar) dan juga jasmaninya (keadaan dhohirnya). Unsur ketiga yakni kurikulum, pada kurikulum materi pembelajaran menjadi pusat dari berbagai pertimbangan dalam memilih metode dan media pembelajaran. Pada tahun 1983 kurikulum madrasah dibagi menjadi tiga tingkatan yaitu diniyah awwaliyah, Diniyah wushto, Diniyah ulya. ${ }^{6}$

Dimensi proses pada pembelajaran diniyah merupakan salah satu hal yang perlu diperhatikan dalam mutu pendidikan. Proses pencapaian merupakan mutu yang menjadi inti. Selain itu terdapat beberapa hal yang mempengaruhi pencapaian mutu di Madrasah Diniyah yaitu standar nasional pendidikan, prioritas kebutuhan pendidikan, aspirasi orang tua, dan aspirasi masyarakat. Untuk menciptakan pembelajaran yang efektif, peserta didik diproses dengan mutu pembelajaran yang baik sehingga hasil pembelajaran berjalan sesuai standar yang diinginkan. Dalam melaksanakan proses pembelajaran, terdapat beberapa macam pendekatan pembelajaran yang diterapkan. Salah satunya yakni pembelajaran terpadu yang merupakan pendekatan dalam proses pembelajaran yang melibatkan bidang studi dengan cara memberikan pengalaman langsung dalam memahami konsep-konsep yang telah dipelajarinya dan menghubungkannya ke konsep-konsep yang sudah difahami oleh peserta didik. Terdapat tiga strategi yang dilakukan dalam meningkatkan mutu pendidikan: Pertama, penyelenggaraan tabkik atas kitab karya Ulama nusantara, Kedua, Sosialiasi pemahaman keagamaan yang toleran, seimbang, moderat, dan cinta tanah air. Ketiga, penyelenggaraan deradikalisasi keagamaan pada lembaga pendidikan kegamaan.

Dalam PP 73 Pasal 22 Ayat 3 disebutkan bahwa Madrasah Diniyah termasuk kelompok pendidikan keagamaan yang berada di luar jalur sekolah dan dilembagakan yang memiliki tujuan untuk mempersiapkan serta menciptakan peserta didik yang memiliki dan menguasai pengetahuan agama Islam yang dibina

"Sabar Junanto, "Evaluasi Pembelajaran Madrasah Diniyah Miftachul Hikmah Denayar Tangen Sragen," Tarbawi 1, no. 2 (2016): 183. 
oleh Menteri Agama. Dalam sejarah perkembangan madrasah di Indonesia, terdapat dua jenis madrasah yaitu: pertama, Madrasah Diniyah merupakan sebuah lembaga pendidikan Islam yang memiliki kurikulum sepenuhnya materi agama. Kedua, madrasah non diniyah merupakan sebuah lembaga pendidikan Islam namun kurikulumnya terdapat mata pelajaran umum dan memiliki persentase yang beragam. $^{7}$ Kurikulum sendiri memiliki arti suatu jarak yang harus ditempuh. Sedangkan dalam dunia pendidikan kurikulum memiliki arti sejumlah mata pelajaran yang diajarkan oleh pendidik dan harus ditempuh untuk mencapai tujuan pendidikan. Dalam arti luas kurikulum diartikan seluruh aktifitas yang dilakukan peserta didik dan direncanakan oleh lembaga pendidikan serta mencakup pengalaman-pengalaman yang diberikan peserta didik dalam bentuk kognnitif, psikomotorik dan juga afektif. Madrasah Diniyah juga merupakan suatu lembaga yang sudah seharusnya memiliki kurikulum dalam bentuk mata pelajaran, yang tersusun secara sistematis berdasarkan visi-misi yang terdapat di Madrasah Diniyah tersebut. Kurikulum juga memiliki komponen-komponen yang saling berhubungan dan berkaitan erat dalam proses pembelajaran, komponenkomponen tersebut yakni tujuan, isi, organisasi, dan strategi. Menurut Ibrahim (1986) pada tahun 1991 kurikulum dibagi menjadi tiga tipe, Pertama, Tipe A yang memiliki fungsi membantu dalam penyampaian tema dalam pendidikan agama terutama dalam hal praktek dan latihan ibadah serta membaca al-Qur'an. Kedua, Tipe B yang memiliki fungsi dalam meningkatkan pengetahuan agama Islam sehingga setara dengan madrasah yang berorientasi pada kurikulum madrasah MI, MTS dan MA. Ketiga, Tipe C yang memiliki fungsi dalam pendalaman agama yang memiliki sistem pondok pesantren. ${ }^{8}$.

Untuk menghasilkan mutu pendidikan yang diinginkan oleh visi misi madrasah, maka sebuah madrasah perlu memiliki standar mutu yang dapat dijadikan pedoman dalam menilai output pendidikan madrasah tersebut, sehingga setiap tahunnya mutu pada madrasah tersebut terjamin kualitasnya. Terdapat langkah-langkah standar mutu pendidikan sesuai stadar Nasional pendidikan,

${ }^{7}$ Muhammad Kosim, “Madrasah Di Indonesia,” Tadris 2, no. 1 (2007): 42.

${ }^{8}$ Marwin Salahuddin, "Pengembangan Kurikulum Madrasah Diniyah Takmiliyah," Cendekia 10, no. 1 (2012): 48. 


\section{Meningkatkan Mutu Pendidikan Islam di Madrasah Diniyah Babus Salam \\ Blingoh Donorojo Jepara}

dalam pelaksanaanya: pertama, Standar kompetensi lulusan yang diguanakan untuk pedoman penilaan kelulusan peserta didik, dalam standar kompetensi lulusan terdapat standar kompetensi lulusan minimal satuan pendidikan dasar dan menengah dan standar kompetensi kelompok mata pelajaran, dan standar kompetensi mata pelajaran. Kedua, Standar isi yakni memuat kerangka dasar dan struktur kurikulum, serta beban belajar, dan kalender pendidikan. Ketiga, Standar proses meliputi proses pembelajaran yang efektif artinya pembelajaran diselenggarakan dengan interaktif, inspiratif, dan dapat memotivasi peserta didik, memberikan ruang yang cukup bagi bakat minat peserta didik. Keempat, Standar pendidikan dan tenaga kependidikan yaitu seorang guru harus memiliki kualifikasi akademik dan kompetensi, sehat jasmani dan rohani, serta memiliki kemampuan untuk mewujudkan tujuan pendidikan nasional. Kelima, Standar sarana prasarana yaitu sebuah lembaga harus memiliki sarana prasarana yang memadai, contohnya seperti buku sumber belajar, media pembelajaran, ruang kelas, dan lain-lain. Keenam, Standar Pengelolaan yang terdiri menjadi tiga bagian yaitu standar pengelolaan yang dikelola oleh lembaga itu sendiri, pengelolaan pemerintah daerah dan standar pengelolaan pemerintah pusat. Ketujuh, Standar pembiayaan yakni meliputi biaya operasi, personal, dan biaya yang digunakan untuk menunjang sarana prasarana. Biaya operasi yang dimaksud disini adalah gaji pendidik dan tenaga kependidikan, bahan peralatan pendidikan, biaya oeprasi pendidikan tak langsung meliputi air, daya, telekomunikasi, transportasi, pajak, asuransi, dan lainlain. Kedelapan, Standar penilaian pendidikan yang mencakup penilaian hasil belajar dari pendidik, pemerintah, dan lembaga itu sendiri. ${ }^{9}$

Di dalam meningkatkan mutu pendidikan juga terdapat perencanaan pendidikan yang matang untuk menghasilkan pembelajaran yang efektif. Perencanaan merupakan suatu cara untuk menyeimbangkan dan mengantisipasi sebuah perubahan. Menurut Roger A. Kauffman, perencanaan merupakan proses dalam penentuan jalan maupun sasaran yang ingin dicapai serta menetapkan jalan maupun sumber yang dibutuhkan dalam mencapai sebuah tujuan yang efektif dan efisien. ${ }^{10}$ Sedangkan perencanaan pendidikan merupakan suatu kegiatan untuk

${ }^{9}$ Hasnani, Pengendalian Mutu Sekolah (Riau: PT Indagiri Dot Com, 2019).

${ }^{10}$ Abin Udin, Perencanaan Pendidikan (Bandung: Rosdakarya, 2011). 
melihat masa depan dalam hal menentukan prioritas, kebijakan, dan biaya pendidikan dengan memperioritaskan kenyataan yang ada. Terdapat empat hal dalam perencanaan pendidikan, yaitu Pertama, Tujuan yang akan dicapai dalam sebuah perencanaan, Kedua, keadaan yang terjadi pada masa sekarang, Ketiga, alternatif pilihan pada kebijakan, dan prioritas dalam mencapai tujuan, Keempat, strategi penentuan cara terbaik untuk mencapai sebuah tujuan. ${ }^{11}$

Perencanaan mutu pendidikan dilakukan melalui adanya komponenkomponen strategi pendidikan (penyusunan strategi, penerapan stategi, dan juga evaluasi strategi). Perencanaan mutu pendidikan pada Madrasah Diniyah dapat dilakukan dengan tahap-tahap yaitu: Pertama, Perumusan tujuan mutu pembelajaran (tercapainya standar pada proses pendidikan nasional yang berkaitan dengan pelaksanaan proses belajar mengajar pada lembaga pendidikan agar memenuhi kompetensi lulusan. Kedua, perumusan ruang lingkup mutu pembelajaran, ruang lingkup ini mencakup komponen-komponen pembelajaran, kualitas, kondisi lingkungan, kondisi pendidik dan peserta didik, sumber belajar, lingkungan belajar. Ketiga, menetapkan jangka waktu pencapaian mutu pembelajaran. Keempat, menetapkan metode pengembangan mutu. Kelima, menetapkan alat yang diperlukan dalam proses pembelajaran. Keenam, merumuskan Evaluasi.

Pada pelaksanaan program madrasah berdasarkan Peraturan Mendiknas Nomor 19 Tahun 2007 Tentang Standar Pengelolaan Pendidikan Oleh Satuan Pendidikan Dasar dan Menengah dibagi menjadi tiga aspek, yaitu penyusunan pedoman madrasah, struktur organisasi, dan pelaksanaan kegiatan. Pedoman disini meliputi dokumen-dokumen disini merupakan dokumen yang tertulis dan mudah dibaca oleh orang-orang yang mengelola lembaga tersebut, struktur organisasi sendiri memiliki makna bentuk terstruktur dari penyelenggara dan administrasi sebuah lembaga yang diurasian secara jelas dan transparan. ${ }^{12}$

2. Mutu Madrasah Diniyah di Babus Salam Blingoh Donorojo Jepara

\footnotetext{
${ }^{11}$ Undang Ruslan Wahyudin, Manajemen Pendidikan: Teori Dan Praktik Dalam Penyelenggaraan Sistem Pendidikan Nasional (Yogyakarta: Deepublish, 2020).

${ }^{12}$ Ahmad Qurtubi, Administrasi Pendidikan Tinjauan Teori Dan Implementasi (Surabaya: Jakad Media Publishing, 2019).
} 


\section{Meningkatkan Mutu Pendidikan Islam di Madrasah Diniyah Babus Salam \\ Blingoh Donorojo Jepara}

Mutu pendidikan setidaknya terdapat tiga hal yang sangat penting yaitu input, proses, dan output. Dalam hal ini Madrasah Diniyah Babus Salam Blingoh Donorojo Jepara telah melakukan beberapa usaha dalam meningkatkan mutu pendidikan Madrasah Diniyah. Hal ini dapat diketahui dari hasil wawancara dengan salah satu guru dalam Madrasah Diniyah tersebut yaitu Ibu Akmil Dinana, menurut beliau dikatakan bahwa input salah satunya yakni jumlah peserta didik yang kian meningkat setiap tahunnya. Hal itu memberikan efek yang sangat positif di dalam Madrasah Diniyah Babus Salam, dikarenakan Madrasah Diniyah Babus Salam merupakan madrasah yang baru didirikan sekitar satu tahun.

Dalam penelitian di Madrasah Diniyah dikatakan bahwa proses terdapat pada penentuan kurikulum dilakukan secara musyawarah yang dilakukan kepala Madrasah Diniyah dan juga guru-guru Madrasah Diniyah Babus Salam. Di Madrasah Diniyah Babus Salam belum terlalu banyak materi pelajaran yang disediakan, hal ini dikarenakan minimnya orang yang mau menjadi guru di Madrasah Diniyah tersebut. Materi pelajaran Madrasah Diniyah Babus Salam hanya terdapat empat materi pelajaran yaitu mata pelajaran al-Qur'an Hadits, Fiqh, Akidah Akhlak dan juga Tajwid. Hal itu yang membuat Madrasah Diniyah Babus Salam ini sangat lemah dalam mutu pendidikannya. Maka meningkatkan mutu pendidikan di Madrasah Diniyah Babus Salam sangat penting untuk dilakukan, agar Madrasah Diniyah Babus Salam tetap berjalan dan semakin maju kedepannya. Dengan mata pelajaran yang belum sempurna diharapkan ketika mutu pendidikan meningkat maka kurikulumnya bisa mengikuti madrasah-Madrasah Diniyah pada umumnya.

Dalam mutu pendidikan selain input, dan proses, terdapat output yakni adanya evaluasi pembelajaran. Adanya evaluasi atau penilaian ini bertujuan untuk menunjukkan mutu yang dicapai Madrasah Diniyah. Ketercapaian Madrasah Diniyah dalam meningkatkan mutu pendidikan dapat dilihat dari hasil output yang baik. Selanjutnya pada output Madrasah Diniyah di Babus Salam yakni adanya evaluasi atau penilaian pada peserta didik, untuk mengetahui hasil pada pembelajaran apakah sudah memenuhi standar ataukan masih kurang memenuhi standar. Penilaian di Madrasah Diniyah Babus Salam menggunakan penilaian normatif (untuk mengetahui sejauh mana peserta didik menguasai materi dengan 
baik dari bentuk materi yang sudah ditentukan), Kedua, Sub sumatif (penilaian yang digunakan untuk mengetahui tingakt pemahaman peserta didik pada sub materi yang telah diberikan oleh pendidik), Ketiga, Sumantif (penilaian yang digunakan untuk mengetahui tingkat penguasaan siswa terhadap kumpulan materi-materi yang telah diberikan oleh pendidik). menurut hasil wawancara pada tahap penilaian berjalan cukup baik. hal ini di tandai dengan nilai-nilai yang baik pada waktu evaluasi itu berlangsung.

Dalam upaya meningkatkan mutu pendidikan, Madrasah Diniyah Babus Salam juga menggunakan metode yang direncanakan secara matang oleh kepala Madrasah Diniyah dan juga para guru. Bebarapa metode yang terdapat di Madrasah Diniyah Babus Salam adalah metode ceramah, sorogan (atau mengaji kitab kuning), hafalan disini ada beberapa macam hafalan mulai dari surah-surah pendek, asmaul husna, sampai menghafal sifat-sifat Allah, Nabi dan Rasul, dan masih banyak lainnya. Di Madrasah Diniyah Babus Salam juga terdapat praktik ibadah yang dilakukan berbagai macam yakni membaca asma'ul husna dan do'a kepada orang tua sebelum pembelajaran dimulai, pembacaan aqoid lima puluh dalam pelajaran akidah akhlak, melaksanakan praktik sholat tahajud dan juga sholat janazah, serta sholat-sholat sunnah lainnya.

Berdasarkan uraian diatas, terkait meningkatkan mutu pendidikan madarasah diniyah di Blingoh Donorojo Jepara maka perlu dilakukan penambahan mata pelajaran, dengan adanya penambahan materi pembelajar dapat membuat peserta didik mengenal ilmu-ilmu baru dan juga mendapatkan wawasan baru dalam belajar. selain itu fasilitas dalam sarana prasarana juga perlu ditingkatkan dalam sebuah lembaga pendidikan karena sarana prasarana juga mempengaruhi tercapainya hasil pembelajaran.

Hambatan yang dialami Madrasah Diniyah pada saat ini dapat dilihat dari anggapan masyarakat bahwa mutu pendidikan di Madrasah Diniyah sangat rendah. Meskipun Madrasah Diniyah mampu menunjukkan mutu pendidikan yang tinggi namun generalisasi masyarakat masih menganggap bahwa mutu pendidikan Madrasah Diniyah masih rendah. Terdapat banyak problema bagi Madrasah Diniyah: pertama, dari kondisi pendidik yang belum memadai. Kedua, minimnya sarana prasarana dalam pendidikan. Ketiga, ketidaksempurnaan kurikulum 


\section{Meningkatkan Mutu Pendidikan Islam di Madrasah Diniyah Babus Salam \\ Blingoh Donorojo Jepara}

pendidikan di dalam Madrasah Diniyah. Keempat, Minimnya prestasi peserta didik yang sangat berpegaruh dalam mutu pendidikan Madrasah Diniyah itu sendiri. ${ }^{13}$

\section{Hambatan dalam Peningkatan Mutu di Madrasah Diniyah Babus Salam}

Hambatan yang terdapat di Madrasah Diniyah Babus Salam dalam meningkatkan mutu pendidikan Islam, antara lain:

a. Masalah sosial

Secara sosial Madrasah Diniyah Babus Salam menghadapi masalah dalam hal informasi keberadaan, kepentingan, dan fungsi Madrasah Diniyah di dalam masyarakat. Masyarakat cenderung menganggap bahwa Madrasah Diniyah tidak perlu dilakukan karena anaknya sudah belajar di sekolah yakni pendidikan formal, sehingga hal tersebut membuat Madrasah Diniyah kian sedikit peserta didiknya.

b. Masalah ekonomi

Penyelenggaraan Madrasah Diniyah menghadapi masalah pembiayaan yang cukup pelik. Tidak ada kucuran dana khusus untuk pembiayaan Madrasah Diniyah kecuali jika pengelola Madrasah Diniyah mengajukan proposal bantuan kepada Pemerintah melalui Departemen Agama. Jumlah yang diterima dari proposal yang diajukan itu, jika direalisasikan, tidak cukup besar. Sehingga dapat disimpulkan bahwa Madrasah Diniyah Babus Salam mengalami kekurangan dalam hal sarana prasarana, dan menjadi salah satu hambatan untuk meningkatkan mutu pendidikan, misalnya dalam hal anggaran yang seharusnya dapat digunakan untuk membeli buku maupun memperbaiki ruang kelas yang rusak jadi sangat sulit dilakukan, karena kurangnya dana untuk sarana prasarana.

Hal tersebut sesuai dengan Rosyadi, Mujahidin, Muchtar bahwa para pengelola/yayasan pendidikan Islam sering kali mengeluhkan dalam hal kekurangan dana, sarana dan manajemen pendidikan. Kondisi ini sudah 
berlangsung sejak lama yang mengakibatkan keberadaan madrasah diniyah di daerah tidak kondusif sebagai lembaga pendidikan ${ }^{14}$.

Agar mutu pendidikan tidak menurun karena hambatan-hambatan diatas maka dibutuhkan solusi dalam menyelesaikan masalah sosial dan masalah ekonomi di madrasah diniyas Babus Salam. Solusi tersebut bisa didapat dari musyawarah antara kepala madrasah dan para guru, serta tenaga kependidikan dalam menjaga eksistensi Madrasah Diniyah di tengah-tengah masyarakat yang memiliki minat sedikit tentang Madrasah Diniyah itu sendiri, selain itu perhatian pemerintah juga sangat dibutuhkan di dalam menyelesaikan masalah-masalah yang ada, agar nantinya masalah-masalah tersebut dapat terselesaikan dengan baik dan menjadikan meningkatnya mutu pendidikan di Madrasah Diniyah Babus Salam.

\section{Kesimpulan}

Peningkatkan mutu pendidikan pada Madrasah Diniyah Babus Salam Blingoh donorojo Jepara dalam penerapannya menggunakan metode yang tepat, menerapkan input, proses, dan output yang baik. Namun terdapat kendala dalam meningkatkan mutu pendidikan Madrasah Diniyah Babus Salam Blingoh Donorojo Jepara, yaitu kendala dalam masalah sosial yakni kurangnya minat masyarakat untuk memasukkan anaknya ke dalam lembaga pendidikan Madrasah Diniyah, selain itu juga terdapat kendala ekonomi yang terjadi di Madrasah Diniyah yang meliputi kurangnya pembiayaan sarana prasarana dalam Madrasah Diniyah, sehingga membuat mutu pendidikan Madrasah Diniyah semakin rendah. Oleh hal itu maka perlu dilakukan pembenahan sudut pandang dalam masyarakat dalam memandang rendah Madrasah Diniyah dan juga perhatian pemerintah dalam menangani sarana prasarana yang terdapat di Madrasah Diniyah.

\footnotetext{
${ }^{14}$ A. Rahmat Rosyadi, Endin Mujahidin, and Affandi Muchtar, "Kebijakan Pemerintah Daerah Tentang Wajib Belajar Madrasah Diniyah Awaliyah Di Kabupaten Pandeglang," Ta'dibuna: Jurnal Pendidikan Islam 2, no. 1 (2013): 1, https://doi.org/10.32832/tadibuna.v2i1.534.
} 


\section{Daftar Rujukan}

Armaludin, Usman. "Learning Management in Improving the Quality of Graduates Madrasah Diniyah Takmiliyah Awaliyah (MDTA) in Sukabumi District," International Journal of Nusantara Islam Vol.9, No. 1, 2021

Hasnani. Pengendalian Mutu Sekolah. Riau: PT Indagiri Dot Com, 2019.

Huda, Khoirul. "Problematika Madrasah Dalam Meningkatkan Mutu Pendidikan Islam," Jurnal Dinamika Penelitian, Vol. 16, No. 2, 2016.

Ikwandi, Muhammad Ripin. "Peran Madrasah Diniyah Dalam Peningkatan Mutu," Edusiana: Jurnal Manajemen Dan Pendidikan Islam, Vol.4, No.1, 2017

Junanto, Sabar. "Evaluasi Pembelajaran Madrasah Diniyah Miftachul Hikmah Denayar Tangen Sragen," Tarbawi Vol.1, No. 2, 2016.

Kosim, Muhammad. "Madrasah Di Indonesia,” Tadris Vol. 2, No. 12007.

Marwin Salahuddin, "Pengembangan Kurikulum Madrasah Diniyah Takmiliyah," Cendekia 10, no. 1 (2012): 48.

Munawwir, A.W. Kamus Bahara Arab-Indonesia. Surabaya: Pustaka Progesif, 2002.

Nizah, Nuriyatun "Dinamika Madrasah Diniyah: Suatu Tinjauan Historis," Edukasia, Vol.11, No. 1, 2016.

Qurtubi, Ahmad. Administrasi Pendidikan Tinjanan Teori Dan Implementasi. Surabaya: Jakad Media Publishing, 2019.

Rosyadi, A. Rahmat. et.al. "Kebijakan Pemerintah Daerah Tentang Wajib Belajar Madrasah Diniyah Awaliyah Di Kabupaten Pandeglang," Ta'dibuna: Jurnal Pendidikan Islam, Vol. 2, No. 1, 2013.

Udin, Abin. Perencanaan Pendidikan. Bandung: Rosdakarya, 2011.

Wahyudin, Undang Ruslan. Manajemen Pendidikan: Teori Dan Praktik Dalam Penyelenggaraan Sistem Pendidikan Nasional. Yogyakarta: Deepublish, 2020. 